\title{
The relationship between plant quality and yields of glasshouse tomatoes*
}

\section{S. Spithost}

Glasshouse Crops Research and Experiment Station, Naaldwijk, the Netherlands

\section{Summary}

Experiments in plant raising and early cropping of tomatoes under glass showed that the quality of the plant material, measured by the subsequent crop yield, was largely determined by plant size and was therefore a question of quantity. A further investigation covering 55 nurseries in the South Holland glasshouse district showed that there was a wide variation in the tomato plants used for planting out in December for the early $1969 / 70$ crop. In all cases the plants were too small.

For earliness and yields until 18 April 1970, multiple regression equations could be formulated with correlation coefficients of $\mathrm{R}=0.92$ and $\mathrm{R}=0.86$, respectively. According to these equations the effect of plant size on earliness was considerable, but the effect on the yield was less. Further it was found that a higher $\mathrm{NO}_{3}$ level in the plant material resulted in a later date of the first pick, whilst a higher $\mathrm{Na}$ level caused a lower yield. With the data available, an explanation for these statistically reliable relationships could not be advanced. It was also shown that when the same plant material was used there was no relationship between the yields in one cropping experiment and those on the nurseries.

\section{Introduction}

Earlier investigations into the propagation of tomatoes under glass showed the existence of a relationship between plant size and yield (Spithost, 1969) which could be quantified. Apart from the size of the plant material there was little indication of specific quality effects. The variations in the plant material were caused mainly by soil conditions. It was considered desirable therefore to examine the effect of specific plant quality, brought about by, for instance, climatic conditions, on the earliness and yield of tomatoes under glass.

There was also another problem. It was suggested that there were wide variations in the size of the plant material used on commercial nurseries and that this could have an effect on the yield, earliness and profitability of the nurseries. Between 1969 and 1971 a number of investigations were carried out into the following aspects:

1. does the quality of the plant material depend partly on inner properties?

* Publikatie van het Proefstation voor de Groenten- en Fruitteelt onder Glas te Naaldwijk No 210 . 
2. to what extent does the quality of the plant material used for the early heated tomato crop in the South Holland glasshouse district vary and how much effect does this have on earliness and yield?

\section{Methods of investigation}

Samples of the plant material were obtained by cutting off the plants just below the cotyledons. The samples were put into sealed plastic bags to limit transpiration losses during transport to a minimum. As soon after collection as possible, the length, the number of leaves larger than $3 \mathrm{~cm}$, the fresh weight and the dry matter weight of the samples were recorded and chemical analyses were carried out. The number of plant tops used varied between 18 and 50 per sample, depending on the size of the plants.

Uncut samples of plant material were also collected for inclusion in cropping experiments. The yields of these plants were determined be weighing the fresh fruits.

On the nurseries a number of factors were recorded which were considered to have a bearing on the variations in yield. The growers supplied the information on night temperatures and the minimum and maximum day temperatures, supplemented sometimes by our own recordings.

The relative light transmission of the glasshouses was determined by carrying out a number of light measurements with a lux meter inside and outside the glasshouse, after which the average inside reading was calculated as a percentage of the light level outside the glasshouse.

Experimental designs and statistical analyses were carried out according to wellknown methods (Cochran \& Cox, 1957) and multiple regression equations were selected by the stepwise regression procedure (Draper \& Smith, 1966).

\section{Experiment with commercial plant material 1969/70}

Besides the investigation into the relationship between plant quality and earliness and yield on commercial nurseries (Section 5), a cropping trial was organized at the research station for which 21 nurseries contributed plant material. There were also four plots in the trial containing plants propagated on the research station. The trial was conducted in a heated glasshouse block, laid out as a 5 by 5 lattice square with 6 replications and 20 plants per plot. Planting out in the glasshouse borders was done between 15 and 24 December 1969. Each of the six replicates was housed in a separate compartment with its own temperature regime. In three of the compartments the temperature of the air was set at a higher level than in the other three compartments, with the result that beween 24 December 1969 and 9 May 1970 , the average temperature in one set of compartments was $20.9^{\circ} \mathrm{C}$ and in the other $20.3{ }^{\circ} \mathrm{C}$. The difference was caused mainly by the difference in maximum day temperatures.

The data on the plant material are shown in Table 1 . It is clear that the variation in the plant material was very wide. The fresh weights showed much wider vari- 
Table 1. Plant material used in the trial 1969/70.

\begin{tabular}{llcc}
\hline & Minimum & Mean & Maximum \\
Length (cm/plant) & 6.1 & 17.6 & 49.1 \\
Fresh top weight (g/plant) & 1.1 & 8.7 & 49.1 \\
Leaves over $3 \mathrm{~cm}$ (number/plant) & 4.0 & 6.8 & 11.0 \\
$\mathrm{Na}$ content $\left(\% \mathrm{Na}_{2} \mathrm{O}\right.$ in dry matter) & 0.3 & 0.7 & 1.5 \\
$\mathrm{~K}$ content $\left(\% \mathrm{~K} \mathrm{O}^{\mathrm{O}}\right.$ in dry matter) & 8.2 & 10.3 & 12.6 \\
$\mathrm{Mg}$ content $(\% \mathrm{MgO}$ in dry matter) & 0.8 & 1.3 & 1.6 \\
\hline
\end{tabular}

ation than the numbers of leaves larger than $3 \mathrm{~cm}$, which indicates that this is partly a function of the plant variables.

Fruit yields also showed a great deal of variation (Table 2). More fruit was harvested in the compartments with the higher temperature than in those with the lower temperature. The yield regressions for different harvest periods at the two temperature regimes and related to some variables of the plant material are shown in Table 3. Table 3 shows that the multiple correlation coefficients were between 0.90 and 0.86 and therefore rather high. The highest partial correlation coefficients were obtained for plant length which proves that of the external properties of the plant material, the height of the plants is the best indicator of potential yields. The $\mathrm{Na}$ and $\mathrm{K}$, or $\mathrm{Mg}$ contents were also found to be significant indicators although not to the same extent as plant length. In fact, for the yields obtained at the lower temperatures until 18 April 1970, plant length proved to be the only independent variable.

The quantitative effects of plant length and mineral composition may be deduced from Table 2 and 3. Depending on the temperature regime and the duration of the harvest period, the maximum effect of plant length varied between 200 and $271 \mathrm{~kg}$ per $100 \mathrm{~m}^{2}$, the maximum effect of the mineral composition of the plants between 66 and $96 \mathrm{~kg}$ per $100 \mathrm{~m}^{2}$. In the experimental area the length of the plant material had by far the greatest effect on subsequent yields of the crop.

Table 2. Fruit yields $\left(\mathrm{kg}\right.$ per $\left.100 \mathrm{~m}^{2}\right)$ at lower and higher temperature regime in a cropping trial 1969/70.

\begin{tabular}{llccc}
\hline Harvest period & Temperature & \multicolumn{2}{l}{ Yields $\left(\mathrm{kg} / 100 \mathrm{~m}^{2}\right)$} & \\
\cline { 3 - 5 } & & minimum & mean & maximum \\
Until 18 April & low & 34 & 97 & 257 \\
& high & 110 & 209 & 392 \\
Until 19 May & low & 289 & 429 & 615 \\
& high & 431 & 586 & 804 \\
\hline
\end{tabular}


PLANT QUALITY AND YIELD OF GLASSHOUSE TOMATOES

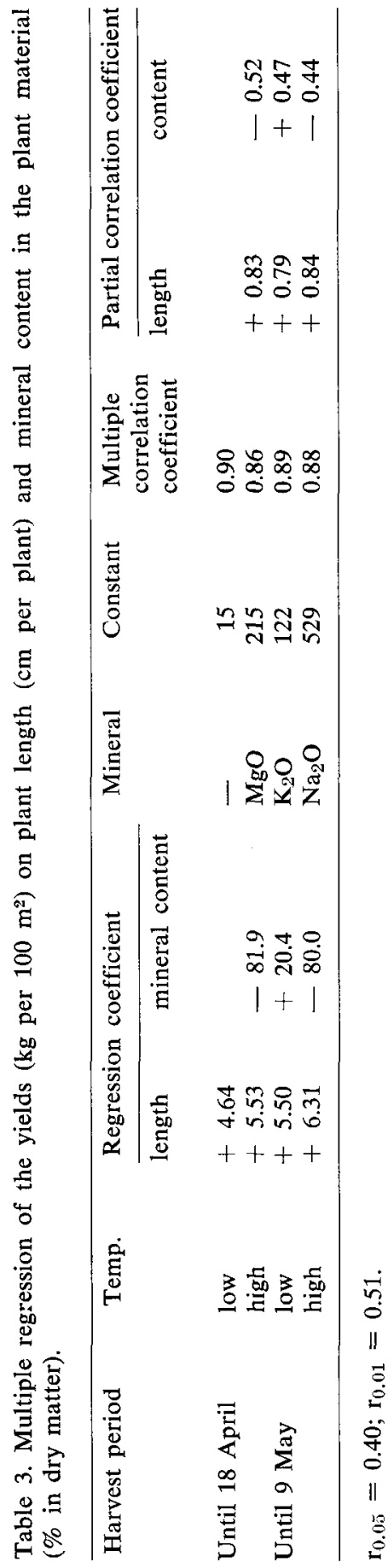

Neth. J. agric. Sci. 23 (1975) 


\section{Plant raising and cropping experiment 1970/71}

The investigation into specific plant material properties was continued with an experiment with early heated tomatoes of cv. 'Extase'. The aim of the experiment was to try and produce two groups of identical plants by varying environmental factors during plant raising and by adjustments in the sowing dates. The second aspect studied was concerned with plant raising temperatures. The following treatments were applied:

1. night temperature $16{ }^{\circ} \mathrm{C}$ and day temperature 20 to $26^{\circ} \mathrm{C}$, light-dependent,

2. night temperature $16^{\circ} \mathrm{C}$ and day temperature $19^{\circ} \mathrm{C}$,

3. night temperature $14^{\circ} \mathrm{C}$ and day temperature $17^{\circ} \mathrm{C}$.

The third factor included in the experiment was watering. Two treatments were applied, a normal water regime and a dry regime. The fourth factor was the nutrient level of the potting compost which was varied by applying a $0.2 \%$ solution of a 20-5-20 compound fertilizer to one group of plants and a $2 \%$ solution to the other group.

All possible combinations of the four factors were included in the experiment. Where the factors caused the growth of the young plants to slow up, an earlier sowing date was used to ensure that the plants within each of the two size groups would be as near identical as possible at the time of planting out. As a result the sowing dates varied between 8 October and 10 November 1970. The experiment was not replicated, but the plants were selected for uniformity and sampled. The length of the young plants, the number of leaves larger than $3 \mathrm{~cm}$, and the fresh and dry weights were determined.

The cropping trial was laid out in the glasshouse borders according to a $3 \times 2^{3}$ balanced design with 6 replicates. Eighteen plants were used in each plot and grown in the normal way.

The most important results, compiled in Table 4, reflect the wide variations found in both the plant material and the crop. Remarkably high correlations were found between the number of fruits on 2 March and the length of the plant material, the yield until 9 April or the yield until 30 April $(\mathrm{r}=+0.98 ; \mathrm{r}=+0.98$; and $\mathrm{r}=+0.99$, respectively).

In linear regression analyses of the yields in relation to plant material variables, the highest correlation coefficients were found for plant length (Table 5). In fact, they were so high that they masked any other possible specific plant material effect. To determine whether any other effects are involved, the yields were subjected to

Table 4. Plant material and crop in the experiment $1970 / 71$.

\begin{tabular}{llll}
\hline Factor & Minimum & Mean & Maximum \\
& & & \\
Plant material, length (cm/plant) & 23 & 50 & 79 \\
Plant material, fresh weight (g/plant) & 14 & 42 & 98 \\
Number of fruits per plant (until 2 March) & 8.0 & 16.3 & 24.6 \\
Fruit yield (kg/plant), until 9 April & 0.01 & 0.25 & 0.58 \\
Fruit yield (kg/plant), until 30 April & 0.86 & 1.37 & 1.87 \\
\hline
\end{tabular}




\section{PLANT QUALITY AND YIELD OF GLASSHOUSE TOMATOES}

Table 5. Correlations between plant length $(\mathrm{cm} / \mathrm{plant})$ and fruit yields $(\mathrm{kg} / \mathrm{plant})$ after different periods in the experiment $1970 / 71$.

\begin{tabular}{llll}
\hline Harvest period & $\begin{array}{l}\text { Correlation } \\
\text { coefficient }\end{array}$ & $\begin{array}{l}\text { Resersica } \\
\text { coefficient }\end{array}$ & Consiant \\
Until 9 April & +0.96 & 0.010 & -0.27 \\
Until 30 April & +0.98 & 0.018 & +0.45
\end{tabular}

variance analyses after corrections had been made based on the plant length of the original plant material. The results showed that there is only a significant effect of the plant raising temperatures on the yields up to 30 April, in the sense that the $16-19{ }^{\circ} \mathrm{C}$ treatment produced $0.1 \mathrm{~kg}$ more fruit per plant than the $16-20$ to $26{ }^{\circ} \mathrm{C}$ treatment. The third treatment $\left(14-17^{\circ} \mathrm{C}\right)$ produced results which were in between those of the other two treatments, but they were not significantly different. However, the specific effects of plant raising temperatures on the general yield level are of minor importance.

\section{Production studies 1969/70}

To come to grips with the practical aspects of the problem, the production factors on a number of commercial holdings were examined. This was done in co-operation with the Agricultural Economics Research Institute in The Hague from whose administration 75 nurseries with an early heated tomato crop were picked. A number of essential production aspects were already recorded by the Institute which were supplemented by information about the crops, such as the plant material used, sowing and planting dates, so that finally 40 factors were recorded. Fifty-five nurseries were used eventually for an analysis of the yields in relation to the factors recorded. The computations included frequency distributions, correlation matrices and multiple linear regressions with 26 independent factors.

The fresh weight of the plant material used on the nurseries varied between 1.7 and $14.3 \mathrm{~g}$ per plant and according to the frequency distribution graph (Fig. 1), the weight range $4.5-5.5 \mathrm{~g}$ was the most widely used. A comparison with Table 1 shows that the experimental plant material used in the investigation described in

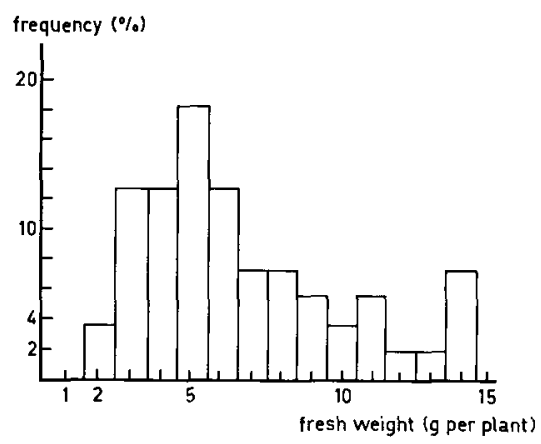

Fig. 1. Diagram of the fresh weights of young tomato plants used on 55 commercial nurseries. 
Table 6. Variations present in important factors in a study of 55 commercial nurseries with and early heated tomato crop.

Factor

First picking (week in 1970)

Fruit yield until 18 April ( $\mathrm{kg}$ per $\left.100 \mathrm{~m}^{2}\right)$

Sowing date (days after 30 September)

Plant age (days)

Plant length $(\mathrm{cm} /$ plant $)$

Leaves over $3 \mathrm{~cm}$ (number per plant)

$\mathrm{Na}$ content plant material ( $\% \mathrm{Na}_{2} \mathrm{O}$ in dry matter)

$\mathrm{NO}_{3}$ content plant material (\% $\mathrm{N}$ in dry matter)

Row spacing $(\mathrm{cm})$

Soil temperature $\left({ }^{\circ} \mathrm{C}\right)^{1}$

Relative light transmission (\% of light outside) ${ }^{1}$

Roof sprinkler $(0=$ no; $1=$ yes $)$

Paraffin usage for $\mathrm{CO}_{2}\left(\mathrm{~kg} / 100 \mathrm{~m}^{2}\right)$

Minimum Mean Maximum

$\begin{array}{ccc}8 & 12 & 15 \\ 3 & 98 & 192 \\ 22 & 35 & 52 \\ 42 & 55 & 70 \\ 8.7 & 16.4 & 32.8 \\ 4.8 & 7.2 & 9.2 \\ 0.3 & 0.8 & 1.5 \\ 0.9 & 1.8 & 2.2 \\ 40 & 48 & 55 \\ 15.2 & 17.2 & 18.8 \\ 53 & 69 & 84 \\ 0 & 0.4 & 1 \\ 0 & 197 & 441\end{array}$

1 On 17 February after the effect of date of survey has been removed.

Section 3 was much larger than the commercial plants which made a poor impression.

Earliness, expressed as the week in 1970 when the first fruit was picked, varied between 8 and 15, or almost two months (Table 6). The average was 12 which is equivalent to the period of 22 to $28 \mathrm{March} 1970$. It should be noted that the earlier the crop, the lower was the assessment figure awarded. Earliness as a function of a number of factors is illustrated in Table 7. The independent factors have been included in the same order of sequence as with the regression analysis with the exception of the leaf numbers which will be explained later.

The multiple correlation coefficient was calculated as $\mathrm{R}=0.92$ so that only $15 \%$ of the total variance remained unexplained. However, it is not only the regression coefficients which are important to obtain an impression of the effects of the factors included in the equation, but also the respective distributions which

Table 7. Multiple regression equation for earliness of the yield (expressed as the week of first picking) in a study of 55 commercial nurseries with an early heated tomato crop.

\begin{tabular}{lllr}
\hline First picking (week in 1970$)=$ & Standard error & F to remove \\
0.15 & sowing date (days after 30 September) & 0.01 & 105.96 \\
$0.10 \quad$ plant age (days) & 0.02 & 28.93 \\
$-0.33 \quad$ soil temperature $\left({ }^{\circ} \mathrm{C}\right)\left(\% \mathrm{~N}_{\mathrm{NO}}\right.$ in dry matter) & 0.11 & 8.37 \\
$1.0 \quad \mathrm{NO}_{3}$ content plant material & 0.3 & 10.81 \\
-0.0024 paraffin usage $\left(\mathrm{kg} / 100 \mathrm{~m}^{2}\right)$ & 0.0009 & 7.56 \\
$-0.08 \quad$ in row spacing $(\mathrm{cm})$ & 0.03 & 6.76 \\
$-0.5 \quad$ leaves over $3 \mathrm{~cm}($ number per plant) & 0.1 & 21.16 \\
+13.2 & & \\
\hline $\mathrm{R}=0.92$ & &
\end{tabular}


are shown in Table 6.

The sowing date which was on average on 4 November 1969 had a regression coefficient of 0.15 . This means that one week later sowing resulted in one week later picking. The sowing dates ranged over a period of 30 days which shows what a large effect the sowing date has on the time of picking.

The age of the plant material had a positive regression coefficient which indicates that the use of an older plant is detrimental to earliness. In view of the maximum age difference of the plants of 28 days, the difference in picking date amounted to almost three weeks.

The nitrate content of the plant material ranged from 0.9 to $2.2 \% \mathrm{~N}$ of the dry matter and was therefore rather high (Ward \& Miller, 1971). An increase in the nitrate content was accompanied by a decrease in yield with a maximum effect of 9 days. The nitrate content was significant and was positively correlated with the $K$ content $(r=+0.41)$. In view of the positive correlation coefficient of $K$ content and yield (Table 3), the $\mathrm{NO}_{3}$ effect cannot be explained as part of a general relationship between the mineral content of the plant material and the subsequent development of the crop.

Finally, there is the plant material variable of the number of leaves larger than $3 \mathrm{~cm}$. An increase in the number of leaves has a beneficial effect on earliness with a maximum effect of more than 2 weeks. In view of the high $F$ value there is a strong correlation between this plant property and earliness. Plant weight was included initially at the third stage of the analysis as a factor in plant size, but is was eliminated at a later stage of the analysis through the inclusion of the leaf number because of the strong interrelationship between these two factors.

Earliness was of course also encouraged by factors other than the plant material such as higher soil temperatures, increased $\mathrm{CO}_{2}$ enrichment (van Berkel, 1967) and wider planting in the rows. However, these factors will be left out of the discussion.

The yields until 18 April, i.e. the 15th week in 1970, were on an average $98 \mathrm{~kg}$ per $100 \mathrm{~m}^{2}$ (Table 6) and depended on 8 factors (Table 8). The multiple correlation coefficient was $R=0.86$ which means that $75 \%$ of the total yield variance could be explained. Five of the eight factors are connected with the plant material, viz

Table 8. Multiple regression equation for yield until 18 April.

\begin{tabular}{llc}
\hline Yield $\left(\mathrm{kg} / 100 \mathrm{~m}^{2}\right)=$ & Standard error & F to remove \\
+0.20 paraffin usage $\left(\mathrm{kg} / 100 \mathrm{~m}^{2}\right)$ & 0.04 & 22.30 \\
-2.5 sowing date (days after 30 September) & 0.7 & 12.95 \\
$-78 \quad \mathrm{Na}$ content plant material $\% \mathrm{Na}$ O in dry matter) & 23 & 11.97 \\
+2.2 relative light transmission (\% of outside) & 0.7 & 10.78 \\
-4.6 plant age (days) & 0.9 & 25.62 \\
$+31 \quad$ leaves over $3 \mathrm{~cm}$ (number per plant) & 8 & 14.54 \\
$-4 \quad$ plant length (cm/plant) & 1 & 9.87 \\
$+17 \quad$ roof sprinklers $(0=\mathrm{no} ; 1=$ yes) & 8 & 3.98 \\
+151 & & \\
\hline
\end{tabular}

$\mathrm{R}=0.86$ 
sowing date, $\mathrm{Na}$ content of the plants, age of the plants, number of leaves over $3 \mathrm{~cm}$ and length of the plants. One day earlier sowing increased the yield from $100 \mathrm{~m}^{2}$ by $2.5 \mathrm{~kg}$ of fruit. With the sowing dates ranging over a period of 30 days, the maximum yield difference was $75 \mathrm{~kg}$ per $100 \mathrm{~m}^{2}$.

An increase in the $\mathrm{Na}_{2} \mathrm{O}$ content of $1 \%$ caused a yield reduction of $78 \mathrm{~kg}$ per $100 \mathrm{~m}^{2}$, with a maximum reduction of $94 \mathrm{~kg}$ per $100 \mathrm{~m}^{2}$. This effect is practically the same as that achieved in the cropping trial with commercial plant material for the yields recorded until 9 May. On the other hand, in the compartments with the higher temperature regime (Table 3) there is no similarity with these results.

A decrease in the age of the plants of one day, increased the yield by $4.6 \mathrm{~kg}$ per $100 \mathrm{~m}^{2}$ and the yield difference between the shortest plant raising period and the longest was $129 \mathrm{~kg}$.

An increase in the number of leaves larger than $3 \mathrm{~cm}$ increased the yield per leaf by $31 \mathrm{~kg}$ and by $136 \mathrm{~kg}$ per $100 \mathrm{~m}^{2}$ at most. Both factors, age of the plants and leaf number, had an effect on production which was similar to the effect on earliness. The effect of plant length was opposite to the effect of leaf number. An increase in plant length of $1 \mathrm{~cm}$ was equivalent to a yield reduction of $4 \mathrm{~kg}$ per $100 \mathrm{~m}^{2}$. The regression equation length $(\mathrm{cm} /$ plant $)=3.5$ leaves $>3 \mathrm{~cm}$ (number/ plant $)-8.6(\mathrm{r}=+0.72)$ shows that the detrimental effect of increasing plant length is more than compensated for by the yield increase as a result of the increasing number of leaves. In the computation the plant length was included immediately after the introduction of the number of leaves in the regression equation, after which the regression coefficient of the leaf number was also increased appreciably. Apart from the plant properties mentioned above, there was only one independent factor in the comparisons which had a bearing on the crop, viz the paraffin usage for $\mathrm{CO}_{2}$ enrichment. For every $5 \mathrm{~kg}$ increase in the usage of paraffin, the yield was increased by $1 \mathrm{~kg}$ per $100 \mathrm{~m}^{2}$. The maximum effect amounted to 88 $\mathrm{kg}$ per $100 \mathrm{~m}^{2}$.

Finally, there were two factors connected with the technical equipment of the nursery: the relative light transmission expressed as a percentage of the light outside the glasshouse and the presence or absence of roof sprinklers for keeping the glass clean. The regression coefficient of the relative light transmission indicated that for every \% light loss the yield decreased by a little over $2 \mathrm{~kg}$ per $100 \mathrm{~m}^{2}$. This is not a great deal in itself, but the distribution within this factor was so great that the maximum difference was still as much as $68 \mathrm{~kg}$ per $100 \mathrm{~m}^{2}$. The use of a roof sprinkler increased the yield by $17 \mathrm{~kg}$ per $100 \mathrm{~m}^{2}$.

The financial results of the yields until 18 April obtained on the commercial nurseries investigated, varied between 6 and 492 guilders per $100 \mathrm{~m}^{2}$, with an average of 229 guilders. There was a high correlation between the financial results in guilders per $100 \mathrm{~m}^{2}$ and the crop yield in $\mathrm{kg}$ per $100 \mathrm{~m}^{2}$, expressed by the following equation:

financial results in guilders $=2.55 \mathrm{~kg}-19(\mathrm{r}=+0.99)$. The standard error of the regression coefficient amounted to $s=0.05$. The presence of the constant is a result of reducing prices as the season progressed which, if this had been the case, would have given nurseries with earlier yields higher average returns. More- 
over, the high correlation coefficient shows that the financial results can be explained almost entirely by the yields and that differences in grade and quality, as well as the auction to which the fruit was supplied, had practically no effect on the financial results.

\section{Discussion and conclusions}

The results of both cropping trials showed the strongest correlation between early yield and plant length which confirmed the results of previous investigations (Spithost, 1969). In the first experiment (Section 3) there were no significant differences in the regression coefficients of the plant length in the equations for the higher and the lower temperature regimes. This indicates that there was no specific interaction between plant length and the cropping temperature. This would mean that the effect of plant size on subsequent yield is independent of the climatic conditions during the cropping period.

According to the plant raising and cropping trial described in Section 4 an internal quality effect was found which was an effect resulting from the plant raising temperature. However, in relation to the overall effect it was practically negligible. In other words, the quality of the plant material for an early heated crop is almost entirely a question of plant size or plant quantity.

Besides plant size, the mineral composition of the plant material proved an important factor in the experiment with commercial plant material. However, the various regression equations all included different mineral contents, viz magnesium, potassium or sodium. In assessing whether there is question of a functional effect, it should be borne in mind that the potassium content correlated with both the magnesium content $\left(r_{\mathrm{K}, \mathrm{Mg}}=-0.62\right)$ and the sodium content $\left(\mathrm{r}_{\mathrm{K}, \mathrm{Na}}=-0.54\right)$. There was also a significant relationship between the potassium content and the length of the plant $\left(\mathrm{r}_{\mathrm{K}, 1}=+0.53\right)$. Although there were no significant correlations between plant length and the contents of sodium and magnesium, the other intercorrelations make it difficult to give accurate interpretations of the presence of the contents in the multiple regression equations.

The same was true for the $\mathrm{NO}_{3}$ content or the $\mathrm{Na}_{2} \mathrm{O}$ content in the regression equations for earliness and the yields obtained on the nurseries. According to the correlation matrix, there was a most significant correlation between the $\mathrm{Na}$ content and all the factors connected with crop development, in the sense that a higher $\mathrm{Na}_{2} \mathrm{O}$ content in the plant material had a detrimental effect on subsequent growth of the crop. It is probable that the correlations between the chemical composition of the plant material and the crop results are partly true and partly the result of indirect relationships. For example, varietal differences could play a rôle as the nursery investigations were not limited to one and the same variety. Further work may shed more light on this aspect.

With regard to the commercial plant material it could be said that generally wide variations were found. Compared with an investigation carried out in 1960 (Spithost, 1969), there was little difference in the range of plant weights recorded in spite of an interval of nine years. Taking into account that there must be an op- 
timum plant size from the point of view of handling, one cannot escape the conclusion that on the whole commercial plant material was much too small, particularly if one considers the effect of the plant material on the subsequent yields.

Amongst the variables of the plant material the sowing date was most important, and its effect needs no further explanation. Increasing plant age had an unfavourable effect. As the aftereffects of poor conditions during plant raising are less if the plants are planted out in a younger stage (Spithost, 1964), the relationships found in the experiments could be an indication that conditions during plant raising were often below the optimum.

An increase in the number of leaves over $3 \mathrm{~cm}$ had a beneficial effect.

The close correlation between plant length and the number of leaves generally and the fact that in linear regressions the variable with the highest correlation coefficient is selected, merely shows that in principle there is no antagonism between plant length and the number of leaves over $3 \mathrm{~cm}$.

However, in the regression equation of the nursery returns a complication cropped up through the inclusion of the plant length with a negative regression coefficient. Nevertheless, the beneficial effect of increasing plant size on the yield was retained. It is possible that the inclusion of plant length should be seen more as a result of the computation method used than as a true effect.

The effect of the plant material on yields was much greater in the experiments than in the nursery investigation. As there were 19 treatments in both projects, it was determined whether there was a correlation between the respective yields. After the data had been divided into high and low temperature treatments, it was found that the correlation coefficients of the experimental yields and the commercial yields for the harvest period until 18 April were $r=+0.05$ and $r=+0.07$, respectively. There was therefore no relationship whatsoever, although it might have been expected to exist. Apparently there were one or more factors which prevented this. There might be a kind of countereffect on the nurseries which could have worked like this: after planting out larger plants there was rapid growth which the growers purposely controlled on the supposition that controlled vegetative growth is beneficial for flower formation and fruit set. Besides this there may have been other factors which were not covered by the investigation but which were connected with the fact that on the nurseries included in the investigation the possibilities of good plant material were not used to the best advantage.

\section{References}

Berkel, N, van, 1967. $\mathrm{CO}_{2}$ bij tomaten. Groenten en Fruit 22: 1288.

Cochran, W. G. \& G. H. Cox, 1957. Experimental designs, 2nd ed. John Wiley / Chapman \& Hall, New York - London. 611 pp.

Draper, N. R. \& H. Smith, 1966. Applied regression analysis. John Wiley \& Sons, New York London - Sydney. 407 pp.

Spithost, L. S., 1969. Potting media, transplants and yields in the production of glasshouse tomatoes. Veenman, Wageningen. $36 \mathrm{pp}$.

Ward, G. H. \& H. J. Miller, 1971. The influence of fertilization with $\mathrm{KNO}_{3}$ and $\mathrm{NH}_{4} \mathrm{NO}_{3}$ on some nitrogen fractions in tomato seedling tissues. Can. J. Bot. 49: 1643-1646. 